$\left(\begin{array}{lrr}\text { Jpn. J. Hosp. Pharm } & \text { 料 } \\ \text { 資 } & 533-540(1998) \\ 24(5) & 533\end{array}\right)$

ファモチジンロ腔内崩壊錠の服用性に関する患者意識調査

\author{
本田義輝, 中野傎沉* \\ 熊本大学医学部附属病院薬剤部
}

\title{
Evaluation of Preference for Swallowing Orally Disintegrating Famotidine Tablet in Outpatients
}

\author{
YOSHITERU HONDA and MASAHIRO NAKANO* \\ Department of Pharmacy, Kumamoto University Hospital† \\ $\left(\begin{array}{l}\text { Received January 5, } 1998 \\ \text { Accepted May 6, } 1998\end{array}\right)$
}

A survey on the preference of patients for swallowing an orally disintegrating famotidine tablet (OD tablet) was carried out on ulcerous outpatients who had been previously taking a conventional famotidine preparation (either tablet or powder ). OD tablets could be taken without water by about $90 \%$ of these patients. About half of all patients voiced a desire to change to the new OD tablets, while about $20 \%$ chose to continue taking the conventional preparation. Patients over 60 years of age tended to prefer the OD tablets, whereas patients under 60 years of age varied among the individual. The obtained results thus suggest that OD tablets are useful and preferred by patients over 60 years of age.

Key words — famotidine, orally disintegrating tablet, ease of swallowing

\section{はじめに}

経口投与用としては数種類の剤形が臨床応用さ れているが，いずれも長所とともに，それぞれ服 用上の問題点を持っている11. たとえば，散剤は 飛散性や咽頭への付着性, 顆粒剤では義困の間に 詰まったりロ中がザラザラするなどの不快感，ま た, 水剤では味覚嗜好性の問題はもちろん, 計量 の煩わしさなどの欠点が指摘される．さらに，比 較的好まれる剤形である錠剤やカプセル剤におい ても，ある程度以上の大きさになると嚥下困難と なり，逆に小さすぎると取扱い難く視認上の問題

$\dagger$ 熊本市本荘1-1-1; 1-1-1, Honjo, Kumamoto, 8608556 Japan
も生じてくる2,3).

そこで，上記のような欠点を克服した服用しゃ すい経口製剤として，速崩壊性および速溶解性の 製㓮が種々開発され現在上市されつつある ${ }^{4)}$ 。こ のような口の中で薬物を放出するという新規の剂 形に対する評価を行うためには，成分薬物の有用 性を検討することはもちろんであるが，それ以上 にエンドユーザーである患者の印象ならびに要求 度を的確に把握し，それを尊重することが最も大 切と考えられる.

そこで今回，この種の製剤の中で最初に上市さ れたファモチジンロ腔内崩壊錠“ガスター(山之 内製薬 (株)） OD 錠”"5)（以下 OD 錠と略す）を一 つの代表例と考え，新規の易服用性製剤に対する 
患者の意識調査を企画した。

\section{調査方法}

対象は, 従来からファモチジン製剤（ガスター 錠またはガスタ一散）を継続して服用中の外来患 者で，本調査への同意が得られた方に OD 錠を 2-4 週間服用して頂き, その後アンケート用紙 へ無記名で回答を依頼した。アンケート内容は， 口腔内崩壊錠の服用性，利便性打よびファモチジ ン製凨に対する選択性に関係する事がらに焦点を 当て, 従来の服薬状況, 剂形嗜好性, $\mathrm{OD}$ 錠の服 用感, 味, 利点・欠点, 利便性, コンプライアン スへの影響等の各項目の設問で構成した。

症例は，男性20名，女性10名の合計30名で，平 均年歯は59.1歳（20歳代 1 名, 30歳代 4 名, 40歳 代 1 名, 50歳代 7 名, 60歳代10名, 70歳代 6 名打 よび80歳代 1 名)，職業に関しては無職16名（男 性11名, 女性 5 名），有職14名（男性 9 名, 女性 5名）であった。

また別途に，ファモチジン服用患者の年齢層の 実態を把握する目的で, 平成 9 年 9 月第 1 週一第 2 週の 2 週間に打いてファモチジン製郕を処方さ れた外来患者 283 名の年歯構成之, 平成 9 年 9 月 1 力月間の外来受診患者 18,769 名の年齢構成につ いて調査した。な拉，前者は外来処方せんより， また，後者は医事会計情報より，各々集計作業後 に各年齢層の割合を算出した。

\section{結果及び考察}

\section{1. 従来の服薬状況の確認}

$\mathrm{OD}$ 錠に関する質問の前に, 従来の服薬状況を 確認してみると, 図 1 に示すように約半数の患者 が時折薬が飲みづらいと感じることがあると回答 した。この結果に対して別の捉え方をすると，外 来患者の約半数は現在の剂形にほぼ満足している 反面，残り半数の患者はもう少し服用しやすい剤 形の開発を期待しているのではないか，あるい は，飲みやすい剂形を必要としているのではない かと解釈できるものと思われ，より服用しやすい 経口製剂の必要性が改めて示唆された。次に，こ れまで飲まれた薬の剤形の中で，一番飲み難かっ たもの，一番飲みやすかったものを記載してもら うと，やはり散剤を敬遠しがちで錠剤を最も好む という傾向が明確に表れた(図 2)。剤形嗜好性に 関する他施設でのアンケート調查においても，こ

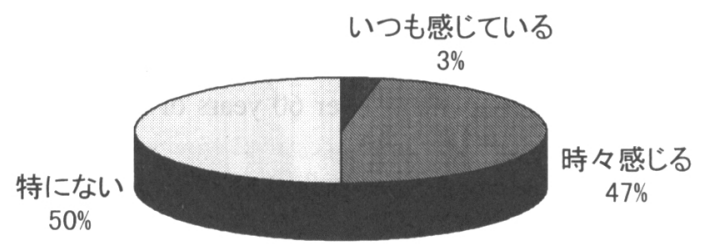

网1。これまでの薬が飲みにくいと感じた ことがありますか？

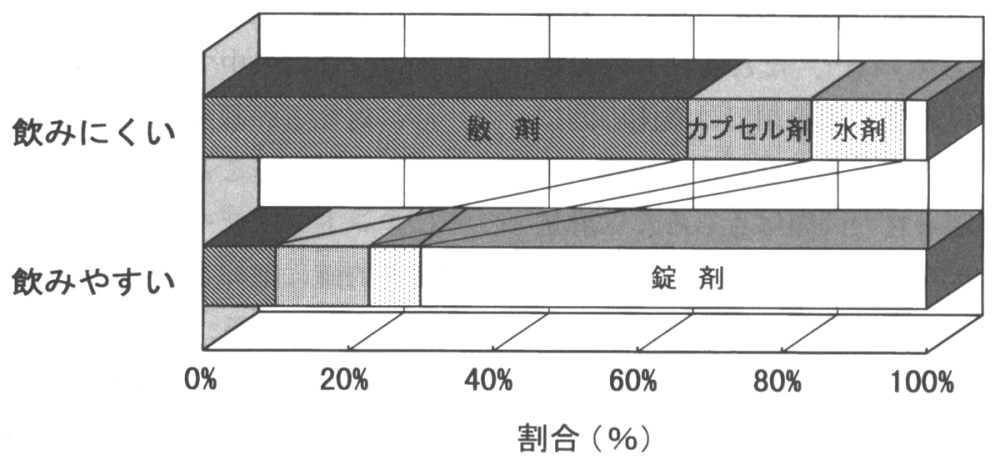

四2。これまで打飲みになられた蔝のうちで一番飲みにくかったもの， 一番飲み易かったものはどれですか？ 
のような傾向が一般的に得られている ら, 今回の対象患者群は普通の感覚を持った症例 群であり，決して特異な対象群ではないことが裏 付けられ，したがって，以下の OD 錠に関する集 計結果も打抢よそ一般的な評価が得られているも のと推察された。

\section{OD 錠の服用性に関する一般的な評価}

新規の郕形である $\mathrm{OD}$ 錠については，「水なし で・・・というキャッチフレーズで宣伝されて いるが，この点をまず確認してみると， 9 割近く の患者は本当に水なしで服用できたようだ（図 3)。ただ，1割強の者は「いいえ」と回答した が、この患者においても, 決して製剤が口の中で 崩壊しなかったという訳ではなく，飲物を必要と した理由は, 後味がどうしても気になって結局飲 物を取ったということであった。本製片はラムネ 菓子のような味覚を持つために, 味が合わない患 者も結構いるのではと調査前には心配したが, 図 4 に示すように, 味についても大方好評であっ た。

では実際服用した患者においては，どのような

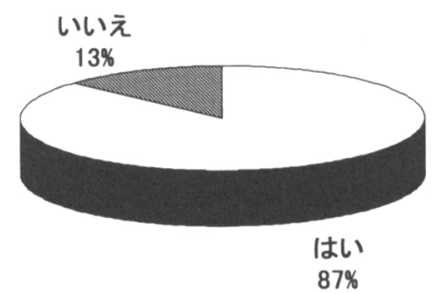

図 3.ガスター OD 錠は本当に水なしで飲め ましたか？

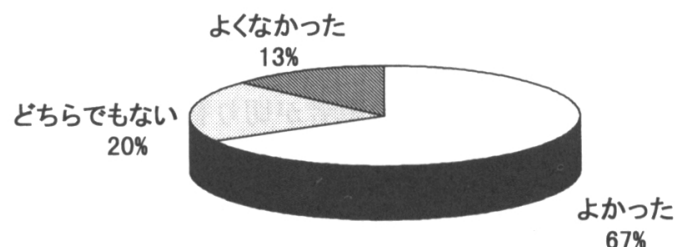

罒4.ガスターOD錠の味はいかがでした か?
ところが良かったか，あるいは，良くなかったか を尋ねると，まず，OD錠の良いところは，「飲 物がいらない」,「飲みやすい」，「味がいい」など を大半の者があげた（表 1 )。

一方，良くなかった点については，本製剤は本 来水と一緒に服用しても構わないが，今回は水な しでの服用をお願いしたために，表２に示すよう に「他の蔝は水や白湯で飲むので，別々に飲む と面倒」という回答があった。また，「製凨が壊 れやすい」,「シートから取り出し難い」なども指 摘されたが, 例数的には, 前述の良いところに比 し少数であった。

本製剤は水なしで飲めるので飲む場所を選ばず 大変便利と宣伝されているが, 実際服用した患者 の利便性に対する反応はというと，図５に示すよ うに“食事の後”扰よび “寝る前”については 4

表 1.ガスター OD 錠の良いところはどんな ところですか？（複数回答可）

〔回答例より]

・水や白湯などの飲物がいらない

(18例)

・これまでの打薬より飲みやすい

・味がいい

・飲み忘れが減りそうだ

(6 例)

[その他]

・トローチ的味覚がさわやかだ

(1 例)

表 2 .ガスター OD 錠の良くないところはど んなところですか？

(複数回答可)

〔回答例より〕

・他のお薬は水や白湯で飲むので，かえって面 倒だ

( 5 例)

・こわれやすい

・シートから取り出しにくい

-味が悪い

・これまでの蔝より飲みにくい

[その他]

・シートから取り出した時に, 粉状のものが周 囲に散る

・これまでのお薬はたくさんの水で飲むように 言われていたので，それとの関係が心配だ

( 1 例) 
表 3 。年齢層からみた郕形嗜好性とガスター OD 錠の味覚評価

片形嗜好性

\begin{tabular}{|c|c|c|c|c|c|}
\hline \multirow{2}{*}{ 剂 } & \multirow{2}{*}{ 形 } & \multicolumn{2}{|c|}{ 60歳未満（13例） } & \multicolumn{2}{|c|}{ 60歳以上（17例） } \\
\hline & & 飲みにくい & 飲みやすい & 飲みにくい & 飲みやすい \\
\hline 錠 & 郕 & 0 & 12 & 1 & 9 \\
\hline \multicolumn{2}{|c|}{ カプセル剂 } & 2 & 0 & 3 & 4 \\
\hline 水 & 戍 & 2 & 1 & 2 & 1 \\
\hline 散 & 剂 & 9 & 0 & 11 & 3 \\
\hline
\end{tabular}

ガスター OD 錠の味覚性

\begin{tabular}{ccc}
\hline 味覚性 & 60歳未満 $(13$ 例) & 60歳以上 (17例) \\
\hline よかった & 6 & 14 \\
よ゙ちらでもない & 3 & 3 \\
よくなかった & 4 & 0
\end{tabular}

[食事の後]

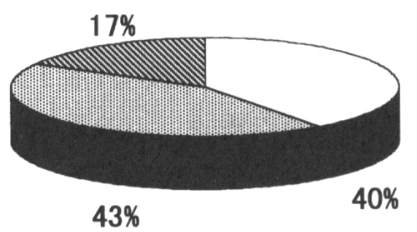

: とても便利
〔寝る前〕

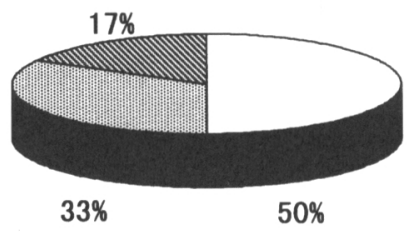

まあまあ便利
〔仕事中，旅行中など〕

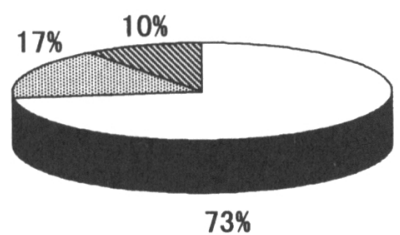

便利と思わない

図 5.ガスター OD 錠は上記の状況の時にどの程度便利だと思われますか？

割から 5 割の者がとても便利と回答し，また特 に，“仕事中や旅行中など”においては約 $3 / 4$ の者が利便性を高く評価した。

また，服用しやすい製剈である以上，そのこと が服薬コンプライアンスの向上に繋がることが理 想であるが，その点について確認してみると，図 6のような回答であった。すなわち, もともと ファモチジンの服用回数は 1 日 2 回ないし 1 回と 少なく, また, 従来の錠剤も取扱いやすく, か つ, 飲みやすい大きさであるため, 従来の製郕に 扔いても，ほとんどの患者がほぼ指示通りに服用 しており，したがって，口腔内崩壊錠へ切り替え ても, 極端なコンプライアンスの向上には繋がら ないものと思われた。ただ，「これまでよりきち んと飲めそうだ」と回答した者も 3 割程度いたこ
とも事実である。曣下機能が低下したり，水分摂 取を制限する必要のある患者などにおいてはコン プライアンスの改善も期待できるかもしれない が, 一般的な外来患者に扔いてはほぼ変わらない か, 若干良くなる患者もいるだろうという程度で はないかと予想された。

次に, 今回のアンケート調査の結論的な回答で あるが，今後はどの製剤を望むかを問うと，約半 数の患者が $\mathrm{OD}$ 錠への切り替えを希望した。た だ,一方では約 2 割の患者が切り替えを拒否し従 来の剂形の継続を希望した（図７）。

3. 年齢層の違いからみた剂形嗜好性及び OD 錠 への評価

困7 の結果は単なる全症例の回答を集計しただ けであるので, この結果を何らかの患者背景因子 


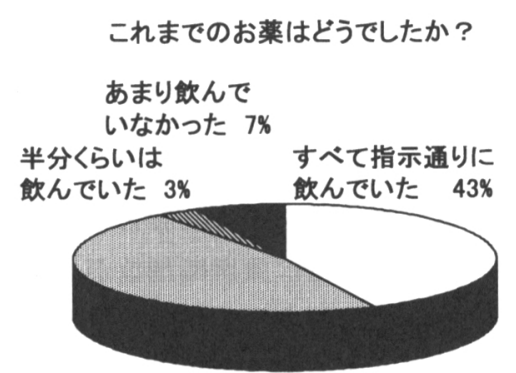

ほとんど指示通りに

飲んでいた $47 \%$
ガスターOD錠に今後切り替えたら

どうなると思いますか?

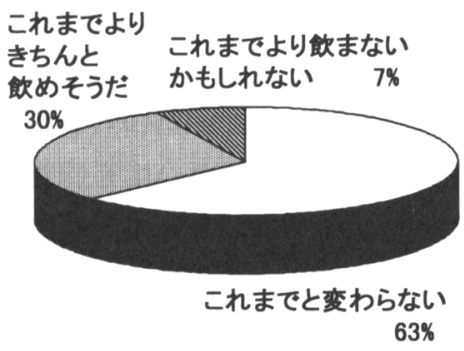

困6.服薬コンプライアンスはどうですか？

から解析できないかと考え若干の検討を行つた。

そこで，今後飲みたいと思う各製剤を選択した 各患者の年齢をプロットしてみたものが図 8 であ

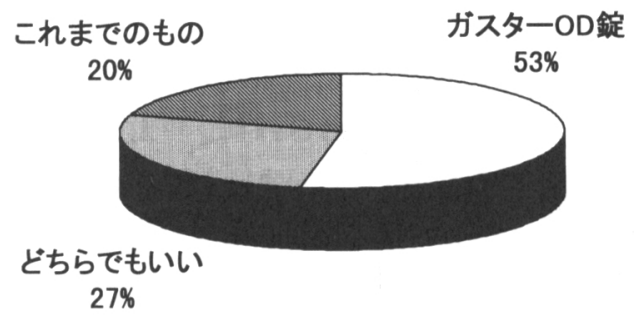

図7.今後飲まれるとしたらどちらがいいで すか?
る。この罒から理解される点は，まず OD 錠を選 択した患者は，29歳の 1 例を除き高齢の者が多い ことがわかる。一方，従来の製剤，つまりこの 6 名に関してはすべて錠剤であるが, 錠剤を選択し た者は多少若い傾向が見られる。つまり，60歳位 を境として製剤嗜好性の変化が窺われた。そこで 60歳のラインで症例を分けて，前述の結果につい て再評価を試みた。表 3 は, 剂形嗜好性と OD の 味に対する評価を60歳の年齢層で区切って比較し たものである。まず，郕形嗜好性に関しては，60 歳未満の患者では錠剤を好むという傾向が顕著に 表れているのに対し，60歳以上の高齢者では，嚥

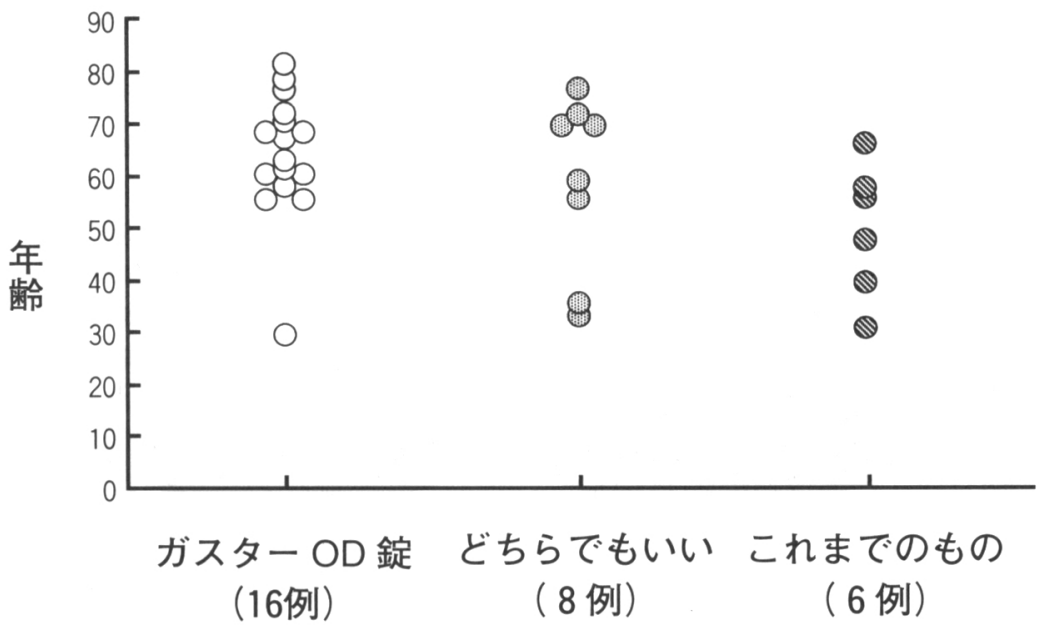

四 8. 年齢からみたファモチジン製剤の嘹好性 
下機能等の差が影響して来てか剂形嗜好性にも個 人差が現れてくることが窅われた。また，OD 錠 の味に関しては, 今度は60歳以上の患者には非常 に好評であったのに対し，60歳未満では意見が分 かれる結果となった。さらに，図９に示すよう に，OD錠の利便性に関する評価においても，60 歳以上の年齢の高い者では全般的に非常に評価す る傾向にあるのに対し，60歳未満の多少年齢の若 い者ではそれほどでもなく，むしろ便利と思わな い患者も相当数いた.

以上のような年歯層からみた剂形嗜好性の差、 ならびに OD 錠への評価の差に基づき，ファモチ ジンに対する製剤選択性には，60歳を境として大 きな違いがあることがわかった（図10)。すなお ち，60歳以上の高齢者は従来の剂形より口腔内崩
壊錠の方を明確に好むのに対し，60歳未満の若い 者は，好みが明確に二分され， OD 錠の評価はあ まり高いものではなかった。 OD 錠を服用するこ とは，曣下機能の低下傾向にある高齢者において は，喉を通過する固形物が 1 つ減ることになり， ある意味では服用薬剤数が 1 種類減るにも等しい ことと理解され，また，ラム不菓子的味覚に関し ても，小児期にラム不を飲んだ世代である高齢者 により受け入れやすい理由と思われた。一方，若 い患者では，わざわざ口中でゆっくり溶かすよ り，むしろ一気に飲み込む方が早くて便利という 認識から，従来の製剤で十分との判断もあるので はないかと推測された。

4.ファモチジン服用患者の年齢構成

このようにファモチジン口腔内崩壊錠は60歳以
〔食事の後〕

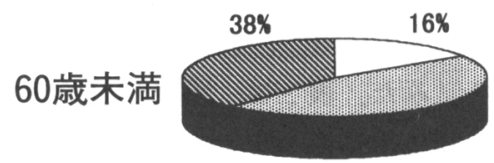

$46 \%$

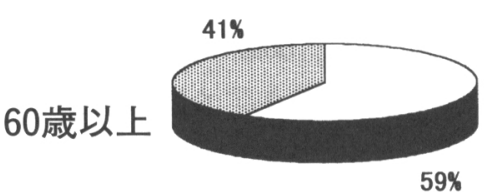

$\square:$ :とても便利
〔寝る前〕

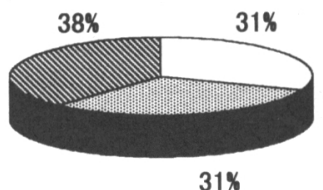

$6 \%$

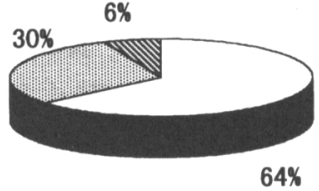

まあまあ便利
〔仕事中，旅行中など〕
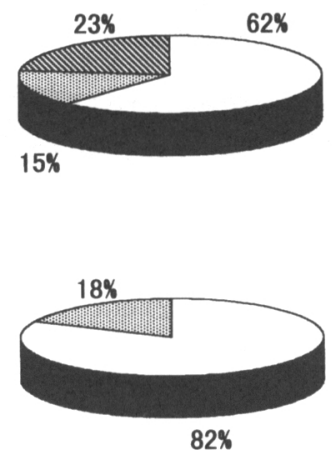

便利と思わない

図 9。年齢層からみた利便性評価

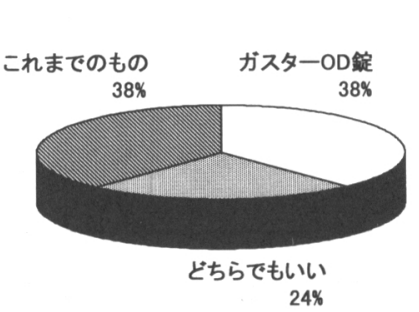

[60歳未満]

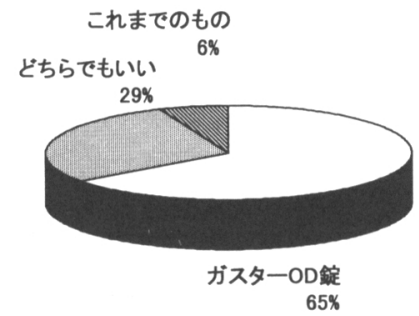

[60歳以上]

四10。年齢層からみたファモチジン製剈の嗜好性 
上の割合高齢の患者に好まれる傾向が明らかとな ったが，ここで確認のために，実際ファモチジン を服用している患者の年齢構成を調査してみる と，図11の右側に示すような割合であった。すな わち，60歳代に大きなピークを持ち，60歳以上が 全体の $55 \%$ も占めていることがわかった．また， この比率は，左図に示す外来受診患者全体の割合 に比べ，非常に高齢者側へシフトしていることも 理解された，高齢になるに従い胃酸分泌は低下す るものの, 胃粘膜における防御因子の減少の方も 著しいため, 結果的には高齢者の方が潰瘍になり やすく，高齢者における潰瘍への対応が現在非常 に問題であることが窥われた ${ }^{7,8)}$. したがって， この点から判断すると, 今回の口腔内崩壊錠の有 用性は高く位置付けられるものと思われた。

なお，本調査における対象患者は，4診療科の 医師に無作為に選択して頂いたが，30名の年齢構 成は，全診療科的にみたファモチジン服用患者の 年齢構成と大きく外れることはないことも確認さ れ，本調査の価値が裏付けられた。

5.アンケート結果を基にしたファモチジンロ腔 内崩壊錠の位置付け

口腔内崩壊錠を想定した発売前のアンケート調 查によると，水なしで服用できる製剤があれば，

受診患者

(平成9年9月集計. 18,769人)

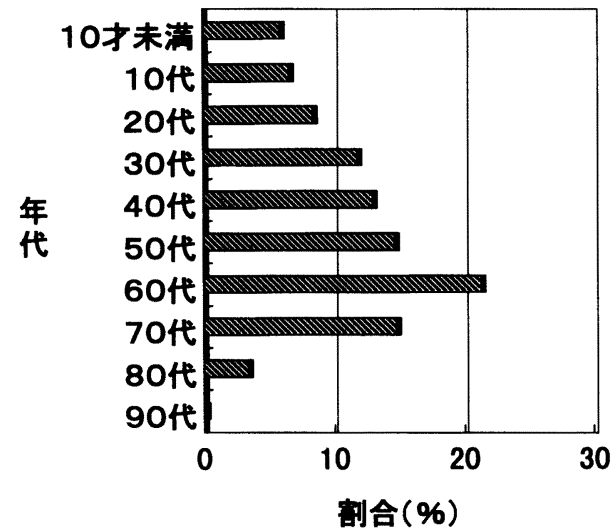

飲む場所を選ばないためコンプライアンスの向上 と副作用防止の面から有用だろうという報告があ $ろ^{9)}$.

しかしながら，実際の治療に供した上で得られ た今回の結果は前者とは若干異なるものであり， 実際服用した外来患者の評価を基にファモチジン 口腔内崩壊錠に対する位置付けを行うと，本製剤 は確かに水なしでも飲めるが，ただ“水なしで飲 める便利な製凨”という捉え方より，むしろ，水 があってもなくても服用しやすく高齢者に好まれ る製剤，つまり，一言で表現するとすれば “高齢 者に優しい製剤”といった捉え方のほうがこの製

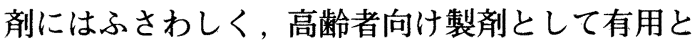
結論付けられた。

また，この評価もあくまでファモチジン製荗と しての口腔内崩壊錠に対するものであり，1日服 用回数の多い他の医薬品や, 従来の錠剤が大きく て飲みづらいような医薬品に本剤形を用いた場合 には，また異なった評価が得られるものと予測さ れる，特に，口腔内崩壊錠としての剂形追加が期 待される解熱消炎鎮痛薬や循環器用薬等では全年 齢層で高い評価が得られるものと思われる，嚥下 機能に問題がある高齢者や幼小児に対する剤形と しては一般的に有用な剤形と位置付けられるだろ

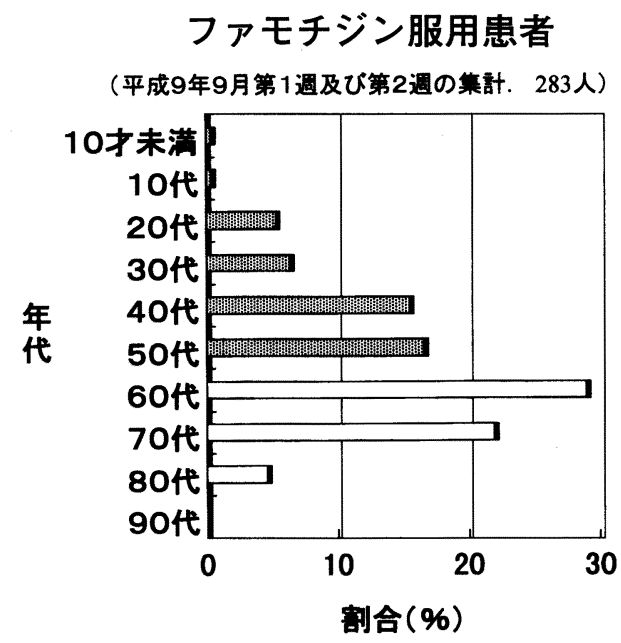

図11. 外来受診患者及びファモチジン服用患者の年齢構成 
う。

最後に, 71藏の女性がアンケート用紙の片隅に 記していた言葉を記す。「常識では, 水は多量使 用するので，果たして水なしでいいかという不安 がある.薬と水との関係の固定観念があるので， ガスター OD 錠の仕組みをわかりたいと思う.」 この言葉から理解できるように，確かに本製片 はこれまでの固定観念を越えた製郕と思われる. そして，このような高秢の患者でも薬効のみなら ず製剤の仕組みまでに興味を持たれていることの 意義は大きく，情報提供の価値がさかんに叫ばれ ている今日，我々はこれらに積極的に応えて行か なければならないと印象を持った。

\section{引用文献}

1) 杉原正泰, ファルマシア， 25, 895-900 (1989).

2) 杉原正泰, 病院薬学, 12, 322-328 (1986).

3) 山田正幸, 沢村正寿, 松浦貞夫, 武田研究所報, 43, 111-115 (1984).

4) 伊東明彦, クリニカルファーマシー, 12(47), 41-47 (1996).

5）正木勝広, 大村忠義, 新薬と治療, 47(4), 1821 (1997).

6) 杉原正泰, Current Therapy, 8, 333-334 (1990).

7) 山下幸政, 木下芳一, 千葉勉, 臨床と研究, 71, 958-962 (1994).

8) 屋嘉比康治, 皆川康孝, 塩島純子, 三村治美, 小柳光仁, 有村隆, 浅井和規, 中村孝司, 臨床 消化器内科, 12, 171-179 (1997).

9) 矢後和夫, 黒山政一, 尾鳥勝也, 新薬と治療, 47(4)，14-17 (1997). 